ARCH. INT. MED.

\title{
THE NATURE AND INTERPRETATION OF THE COLLOIDAL GOLD REACTION*
}

\author{
KARL M. VOGEL, M.D. \\ NEW YORK
}

Owing to the complexity of structure and function of the central nervous system its disorders manifest themselves in clinical picturcs of the utmost variety. Furthermore, in the case of one large group of these affections, the syphilitic and parasyphilitic diseases, it is highly desirable to recognize their nature as early as possible in order that the necessary treatment may be begun and the progress of the malady be arrested before destructive lesions have supervened. The difficulties of diagnosi., are consequently often very great and all suitable methods of investigation yielding objective results are therefore likely to be of much assistance, particularly if they aid not only in diagnosis, but also in observing the effects of treatment. Among such procedures are the various methods of examining the cerebrospinal fluid, such as determining the pressure under which it is held in the spinal canal, counting its cells, testing its globulin content, and carrying out the Wassermann reaction. To this list the experience of the last few years has added another, the colloidal gold reaction, and the observations so far reported indicate that it has a definite value in supplementing the information to be derived from the older sources. It is the intention here to present the results obtained in examining over two hundred cases from a general hospital service in which the colloidal gold reaction of the spinal fluid was tested over 400 times, and to compare these results with those of the other tests.

In order to understand the mode of action of the test it is necessary to step aside for a moment into the domain of the physical chemist, for the colloidal gold reaction is quite different in its principle from the ordinary test tube experiment and involves physical laws not usually called into action in the clinical laboratory.

When Thomas Graham, ${ }^{1}$ in 1861, published his observations on colloids and crystalloids, he apparently regarded them as belonging to wholly different classes, for he said that "They appear like different worlds of matter," two fundamental distinctions being that colloids

\footnotetext{
* Submitted for publication June 19, 1918.

* From the Department of Medicine, Columbia University, and St. Luke's Hospital.

* Read before the Annual Meeting of the Association of the Alumni of the College of Physicians and Surgeons, Columbia University, Jan. 28, 1918.

1. Phil. Tr., Roy. Soc., London, 1861, 151, 183.
} 
do not crystallize, and are unable to pass through the parchment paper septum of a dialysing apparatus. Recent observations indicate, however, that the distinction is one of condition rather than of kind, for under appropriate circumstances many, if not most, substances, can be made to assume either form ${ }^{2}$ and it is therefore preferable to speak simply of the colloidal state, rather than of colloids as a class. In a colloical solution or heterogeneous system, as it is called, in distinction to the solution of a crystalloid, or homogeneous system two components or phases are recognized, the internal or dispersed phase, and the external or continuous phase. Such systems may be composed of solids, liquids, or gases in various combinations. For example, in fog a liquid is the internal phase and a gas the external phase, while in the foam on a glass of beer, the conditions are reversed. In the smoke of a cigaret a solid is dispersed in a gas, in currant jelly a liquid is dispersed in a solid, in a piece of ruby glass copper is dispersed in another solid, and finally, in the gold reagent under discussion a solid forms the internal phase and a liquid the external phase.

Evidently it is not only jellies or substances of a gluey or colloidal nature in Graham's sense that can assume the colloidal state. Solids also, that ordinarily are regarded as entirely insoluble, may be brought into a state of such minute subdivision that their particles remain suspended indefinitely in a fluid medium without settling out, and are then termed suspensoids. They have reached ultramicroscopic dimensions, and approach the molecule in size; that is, they are less in diameter than the wave lengths of the visible spectrum which lie between 700 and 400 microns. An object smaller than half the wave length of the light by which it is illuminated cannot be seen in its true form, for the light is not reflected from its surface, any more than a wave can be reflected from a pebble on the beach, and consequently a colloidal solution appears homogeneous on inspection and the particles of the suspensoid remain invisible, even with the highest magnification. When viewed with the ultramicroscope, however, in which intense lateral illumination is employed, the true nature of the system is revealed, for under these conditions even ultramicroscopic particles become visible by virtue of the Tyndall phenomenon, just as otherwise inappreciable motes may be seen dancing in a ray of sunlight entering a darkened room.

One of the ways in which colloidal solutions or heterogeneous systems differ from ordinary solutions or homogeneous systems is in the fact that in the former there are faces of contact between the external and the internal phase. Consequently the forces of surface tension

2. Bayliss: Principles of General Physiology. London, Longmans, Green \& Co., 1915, p. 109. 
are brought into play, and affect the behavior of the solution. This is especially so since the area of the suspensoid has been increased to an almost unbelievable extent by its transfer to the colloidal state. A sphere of gold $2 \mathrm{~mm}$. in diameter has a surface of 0.126 square $\mathrm{cm}$, while the surface of the same mass if reduced to colloidal particles having a diameter of 10 micromicrons would have an area of about 100 square meters, or ten million times as much. ${ }^{3}$ Siedentopf and Zsigmondy have obtained gold dispersoids with particles of a diameter of less than 6 micromicrons (that is, 6 millionths of a millimeter). For comparison it may be stated that the molecules of starch are estimated to have a diameter of about 5 micromicrons, those of chloroform and of sugar about 0.8 micromicrons, those of carbon dioxid and of sodium chlorid about 0.3 , while the molecule of hydrogen gas, which appears to be the smallest of all, measures only about 0.1 micromicrons. ${ }^{4}$ Gravity has no effect on these suspended particles, which are prevented from settling out of the fluid by the action of forces akin to those responsible for the Brownian movement observed when particles large enough to be visible under high magnifications are examined in a fluid medium under the microscope. Perrin ${ }^{5}$ has shown that this is essentially the same as the molecular movement of the medium in which the particles are held and that it is due to the continual molecular bombardment to which they are subjected. In addition, the electrical charges of the colloidal particles are of importance, particularly in connection with their behavior when brought into contact with solutions of electrolytes. If to a colloidal system holding a suspensoid in this state of equilibrium a solution of a neutral salt, that is, containing ions in the dissociated state, is added, the collcidal particles unite to form groups or aggregates and are precipitated. This may be explained on the supposition that the ions having the opposite electric charge to the colloidal particles become concentrated on the surface of the particles and impart their charge to these, rendering them sensitive to the presence of ions of opposite charge. These in turn neutralize the charge on the particle, and cause the formation of aggregates with resultant precipitation, the effect being the greater the higher the valence, that is, the number of electrical charges, of the ion in question. Occurring on a gigantic scale, this process of flocking out of suspensoids by the action of electrolytes is responsible for the production of the Mississippi river delta through the precipitation of the colloidally suspended particles in the turbid river water which takes place as it mixes with the highly saline waters of the Gulf, while in miniature the chemist utilizes the

3. Bayliss: Principles of General Physiology, 1915, p. 89.

4. Ostwald: A Handbook of Colloid Chemistry. Philadelphia, P. Blakistons Son and Co., 1915, p. 31.

5. Perrin: Comptes rend. de l'Acad. Française, 1908, 146, 967. 
same physical forces when he obtains a water-clear filtrate from a test tube full of blood to which he has added dialyzed iron and a solution of magnesium sulphate.

But still another peculiarity of colloidal solutions has to be considered before we are ready to comprehend the behavior of the reagents in the gold test. If a trace of an emulsoid or reversible colloid like gelatin is added to a solution containing a suspensoid the precipitating action of salt solutions is nullified, and the suspensoid solution is said to be in the protected state. It appears that this protective action is due to the deposition of a film of the emulsoid over each particle of the suspensoid, thus practically converting it into an emulsoid system which is no longer susceptible to flocculation by electrolytes. This principle has been made use of by Schulz and $Z_{\text {sigmondy }}{ }^{6}$ in establishing a so-called gold number for the different proteins. This is the number of milligrams of the given protein required to protect 5 c.c. of colloidal gold from flocculation by 0.5 c.c. of 10 per cent. sodium chlorid solution. It has been found to be a very delicate reaction, and may be used for the quantitative determination of albumins in solution, or for their identification if in pure form. The results of the gold reaction on the spinal fluid appear to depend to some extent at least on differences in the respective protective and precipitating powers of the albumin and globulin of the spinal fluid, the former acting as a protective agent and the latter as a precipitant.

After this brief excursion into the field of physical chemistry we are in a better position to understand the application of the gold reaction to the spinal fluid. The main reagent used is the gold solution, having a beautiful ruby color already familiar to everyone in the splendid hues of cathedral windows, whose wonderful glowing reds are due to colloidal gold in the glass. Faraday, in 1858, made such solutions by the reduction of gold chlorid with phosphorus and carbon disulphid, and a specimen prepared by him is still on view in the Royal Institute in London. Zsigmondy, the same investigator who developed the ultramicroscope while studying the chemistry of glass manufacture, found that better results could be obtained by using formaldehyd as the reducing agent, together with potassium carbonate, ${ }^{7}$ and various modifications of this method have been suggested. Through a lack of understanding of all the factors concerned, much difficulty has been experienced in obtaining proper solutions, for unless the reagent conforms to certain definite requirements it is valueless, and to secure these has been found so difficult that one author

6. Schulz and Zsigmondy: Beitr. z. Chem. Phys., 1903, 3, 137.

7. Zsigmondy : Liebig's Ann. d. Chem., 1898, 301, 29; Ztschr. f. analyt. chem., 1901, 40, 697 . 
(Glaser ${ }^{8}$ ) has gone so far as to say that owing to the uncertainty of being able to prepare a satisfactory reagent the method is unsuited for practical use, and others have described rather complicated methods of manufacture. ${ }^{9}$

\section{TECHNIC}

Colloidal solutions of gold may be obtained in various ways, by reduction, oxidation, hydrolysis, condensation, or dispersion, the latter being effected either by chemical or by electrical means. The method that has been found most practical for the present purpose is that of reduction of gold chlorid in alkaline solution by the action of formaldehyd and oxalic acid. The reagents required are a 1 per cent. solution of gold chlorid, a 2 per cent. solution of potassium carbonate, a 1 per cent. solution of oxalic acid, and a 2.5 per cent solution of formaldehyd. To make a liter of the solution, 10 c.c. of the 1 per cent. gold chlorid solution, 7 c.c. of the 2 per cent. potassium carbonate solution, 1.75 c.c. of the 1 per cent. oxalic acid solution, and 0.83 c.c. of the 2.5 per cent. formaldehyd are added to a liter of distilled water in a chemically clean flask. After thorough mixing the fluid is heated to from 80 to $85 \mathrm{C}$. and kept at that temperature until a series of color changes has taken place, running through gradations from faint blue-green to a deep ruby-red. When the solution reaches its maximum depth of color a remarkable lightening in hue occurs within the space of a few seconds, the dark ruby red becoming converted to a lighter shade, and when this stage is reached, the fluid in thin layers has an orange pink color, and the reaction is finished. If the solution is properly made, 5 c.c. will be completely precipitated in one hour by 1.7 c.c. of a 1 per cent. sodium chlorid solution, showing that it is not "protected," that is, kept from precipitation by electrolytes through the protective action of impurities. In addition, it must give characteristic results with known normal, paretic, and luetic spinal fluids. Full details in regard to a rapid and simple method for preparing the solution may be found in the St. Luke's Hospital Guide to Laboratory Technique ${ }^{10}$ and in an article from this laboratory by O. I. Lee."

To carry out the test, into the first of a series of eleven heavy glass, lipless test-tubes (measuring about $11 / 16$ by 6 inches) 1.8 c.c. of 0.4 per cent. sodium chlorid solution is measured and into each of the remaining ten, 1 c.c. Of the spinal fluid to be tested, 0.2 c.c. is then introduced into the first tube; 1 c.c. of the mixture is placed in the second tube; 1 c.c. of this mixture in the third, and so on up to and including the tenth tube, from which, however, the 1 c.c. withdrawn is rejected, leaving the eleventh tube as a color control. The concentration of the spinal fluid thus ranges from $1: 10$ in the first tube to $1: 5,120$ in the tenth. To each of the eleven tubes is then added 5 c.c. of the colloidal gold solution and the tubes are shaken with a rotary motion to secure thorough mixing.

At the end of half an hour the color of each of the ten tubes is matched against a diffuse white background with the nearest shade selected from the color scale, using the eleventh tube for comparison.

The red or unaltered fluid is given a value of 0 , red-blue 1 , violet-blue 2 , blue 3 , pale-blue 4 , colorless 5 . These color values are then plotted as the

8. Glaser: Neurol. Centralb1., 1914, 32, 688.

9. Miller, Brush, Hammers and Felton: Bull. Johns Hopkins Hosp, 1915, 26, 391 .

10. Wood, F. C., Vogel, Karl M., and Famulener, L. W.: Laboratory Technique. The Methods Employed at St. Luke's Hospital. Ed. 2. New York: James T. Dougherty, 1917, p. 86.

11. Lee, O. I.: A Simple Procedure for the Preparation of Colloidal Gold for Diagnostic Purposes, Am. Jour. Med. Sc., 1918, 155, 404. 
abscissae against the dilutions as ordinates, so as to make a continuous curve, and this constitutes the preliminary reading. At the end of twenty-four hours the values are again read, and this is designated as the final curve, which is usually parallel to the preliminary curve, though a little higher in the scale.

Different affections of the cerebrospinal system produce changes in the spinal fluid which bring about flocking out of the gold solution in different concentrations of the spinal fluid, the varying degrees of precipitation of the gold being characterized by changes in the color of the supernatant fluid, owing to variations in the size of the aggregates of gold resulting, the color becoming bluer as the size of the particles increases. These changes have been found to be fairly consistent, so that it has been possible to establish definite curves or zones of precipitation which seem to be sufficiently reliable to permit of definite diagnostic conclusions, particularly in the case of paresis, tabes, cerebrospinal syphilis and meningitis.

We have records of over 200 cases in which the reaction was performed more than 400 times. This series is of particular interest, because in addition to the syphilitic and parasyphilitic conditions, it comprises so many others of a miscellaneous nature.

Tabes.-The gold reaction is of particular interest in tabes, and of our twenty-four cases, all gave distinctly pathologic curves. The

TABLE 1.-Tabes Dorsalis-Twenty-Four Cases

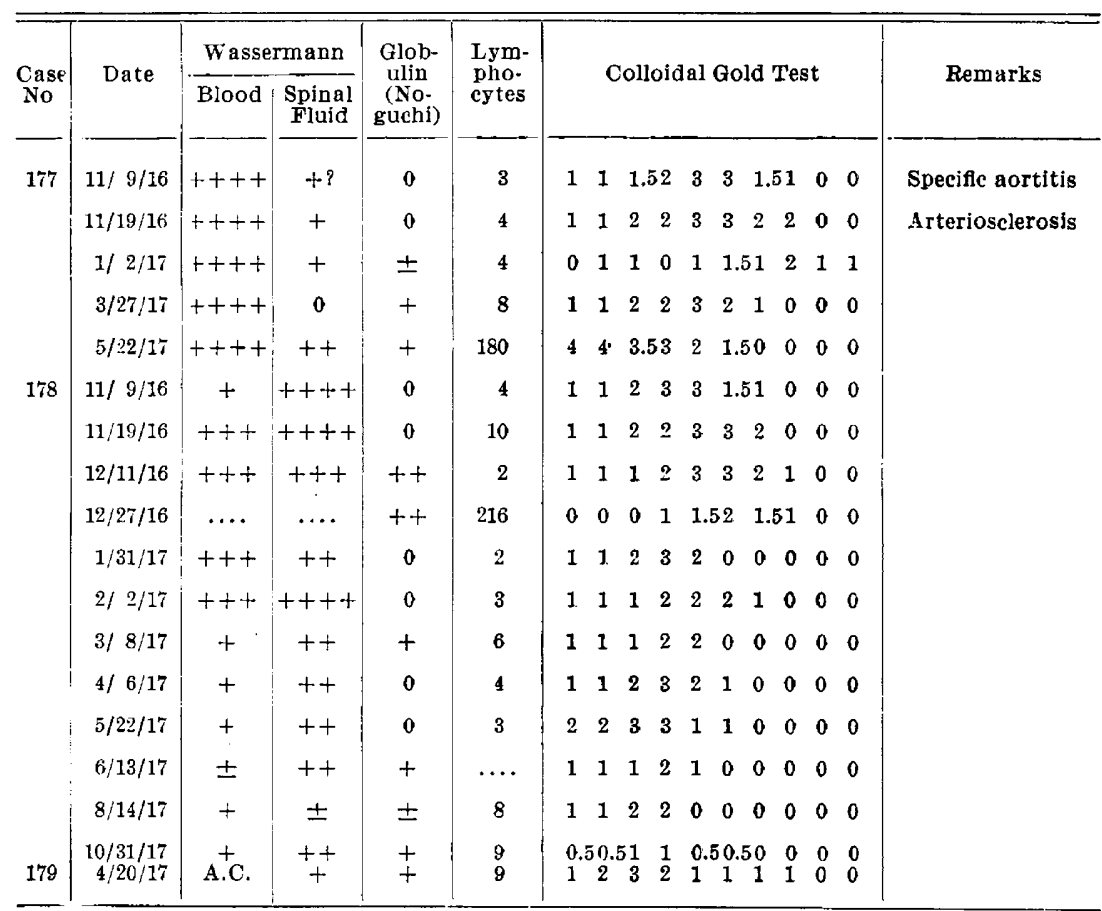


TABLE 1.-Tabes Dorsalis-Twenty-Four Cases-(Continued)

\begin{tabular}{|c|c|c|c|c|c|c|c|c|c|c|c|c|c|c|c|}
\hline \multirow{3}{*}{$\begin{array}{c}\begin{array}{c}\text { Case } \\
\text { No. }\end{array} \\
1 \varepsilon 0\end{array}$} & \multirow{3}{*}{ Date } & \multicolumn{2}{|c|}{ Wassermann } & \multirow{3}{*}{$\left|\begin{array}{c}\text { Glob- } \\
\text { ulin } \\
\text { (No- } \\
\text { guchi) }\end{array}\right|$} & \multirow{3}{*}{$\begin{array}{c}\begin{array}{c}\text { Lym- } \\
\text { pho- } \\
\text { eytes }\end{array} \\
\ldots\end{array}$} & \multirow{2}{*}{\multicolumn{8}{|c|}{ Colloidal Gold Test }} & \multirow{2}{*}{\multicolumn{2}{|c|}{ Remarks }} \\
\hline & & \multirow{2}{*}{$\begin{array}{c}\text { Blood } \\
0\end{array}$} & \multirow{2}{*}{$\mid \begin{array}{c}\begin{array}{c}\text { Spinal } \\
\text { Fluid }\end{array} \\
0\end{array}$} & & & & & & & & & & & & \\
\hline & & & & & & 1 & & & 11 & & & 2 & 1 & $\begin{array}{l}\text { Previous } \\
\text { ment }\end{array}$ & treat- \\
\hline & $2 / 3 / 17$ & 0 & $\ldots$ & $\ldots$ & $\cdots$ & 1 & 1 & 1 & 11 & & 0 & 0 & 0 & & \\
\hline & $2 / 11 / 17$ & 0 & 0 & + & 20 & 3 & 2 & & 30 & 1 & 0 & 0 & 0 & & \\
\hline 181 & $9 / 19 / 16$ & + & ++++ & + & 35 & 5 & 4 & 0 & 23 & 1 & 1 & 1 & 0 & Tertiary syp & philis; \\
\hline & $11 / 11 / 16$ & + & $\ldots$ & + & 12 & 1 & 1 & 1 & 23 & 2 & 1.5 & 1.5 & & nephrosis; & pyeio- \\
\hline & $5 / 8 / 17$ & +++ & ++++ & Faint + & 10 & 1 & 1 & 1 & 20 & 1 & 1 & 0 & 2 & at death & \\
\hline 182 & $7 / 12 / 17$ & 0 & +++ & 0 & 4 & 5 & 2 & 2 & 32 & 1 & 0 & 0 & & & \\
\hline & $7 / 17 / 17$ & $\cdots$ & $\cdots$ & $\cdots$ & 10 & 4 & 4 & 4 & 42 & 1. & 1 & 1 & & & \\
\hline & $9 / 14 / 17$ & + & 0 & $?$ & 10 & 2.5 & 3 & 4 & 21 & 0 & 0 & 0 & & & \\
\hline & $11 / 9 / 17$ & 0 & ++ & 0 & 3 & 5 & 4 & 3 & 20.5 & 0 & 0 & 0 & 0 & & $\cdot$ \\
\hline 183 & $11 / 4 / 16$ & 0 & 0 & 0 & 3 & 1 & 1.5 & 1. & 1.50 & 0 & 0 & 0 & 0 & & \\
\hline 184 & $5 / 19 / 17$ & $\ldots$ & 0 & + & 26 & 1 & 2 & & & 1 & 0 & 0 & 0 & Charcot join & ints \\
\hline 185 & $1 / 29 / 17$ & +++ & ++++ & 0 & 11 & 2 & 2 & 2 & 22 & 0 & 0 & 0 & 0 & $\begin{array}{l}\text { Tertiary sy } \\
\text { chronic }\end{array}$ & $\begin{array}{l}\text { philis; } \\
\text { bron- }\end{array}$ \\
\hline & $2 / 3 / 17$ & $\cdots$ & A.C. & 0 & 24 & 1 & 1 & 2 & $\begin{array}{ll}3 & 3\end{array}$ & 2 & 1 & 0 & 0 & chitis & \\
\hline & $3 / 7 / 17$ & ++++ & ++++ & 0 & 8 & 1 & 1 & 2 & 32 & 1 & 0 & 0 & 0 & & \\
\hline 186 & $1 / \pi / 17$ & A.C. & ++ & + & 4 & 1 & 1 & 2 & 32 & 1 & 0 & 0 & 0 & & \\
\hline & $4 / 13 / 17$ & 0 & $\cdots$ & 0 & 15 & 1 & 2 & 4 & 31 & 0 & 0 & 0 & 0 & & \\
\hline 187 & $10 / 10 / 16$ & 0 & 0 & \pm & 6 & 1 & 1 & 1 & 10 & 0 & 0 & 0 & 0 & $\begin{array}{l}\text { Cerebros } \\
\text { syphilis. }\end{array}$ & $\begin{array}{l}\text { pinal } \\
\text { Previ- }\end{array}$ \\
\hline & $10 / 16 / 16$ & 0 & 0 & + & 6 & 1 & 1 & 1 & 1.51 .5 & 0 & 0 & 0 & 0 & ous treatn & ment \\
\hline & $11 / 24 / 16$ & 0 & 0 & 0 & 4 & 1 & 2 & 2 & 10 & 0 & 0 & 0 & 0 & & \\
\hline & $1 / 9 / 17$ & 0 & 0 & 0 & 4 & 1 & 1 & 1 & 11 & 0 & 0 & 0 & 0 & & \\
\hline & $3 / 17 / 17$ & 0 & 0 & 0 & 3 & 1 & 1 & 2 & 10 & 0 & 0 & 0 & 0 & & \\
\hline & $4 / 24 / 17$ & \pm & 0 & 0 & 4 & 1 & 1 & 2 & 21 & 0 & 0 & 0 & 0 & & \\
\hline & $6 / 5 / 17$ & 0 & 0 & 0 & 4 & 2 & 2 & 3 & 31 & 1 & 0 & 0 & 0 & & \\
\hline & $7 / 5 / 17$ & 0 & 0 & 0 & 4 & 1 & 1 & 2 & 00 & 0 & 0 & 0 & 0 & & \\
\hline & $8 / 17 / 17$ & 0 & 0 & 0 & 4 & 1 & 1 & 1 & 00 & 0 & 0 & 0 & 0 & & \\
\hline & $10 / 13 / 17$ & 0 & 0 & + & 15 & 1 & 1 & & 1.50 & 0 & 0 & 0 & 0 & & \\
\hline & $11 / 13 / 17$ & 0 & 0 & $\ldots$ & $\cdots$ & 1 & 1 & & 0.50 & 0 & 0 & 0 & o & & \\
\hline 188 & $7 / 20 / 16$ & +++ & ++ & + & 24 & 0 & 1 & 2 & 21 & 0 & 0 & 0 & 0 & $\begin{array}{c}\text { Previous } \\
\text { ment }\end{array}$ & treat. \\
\hline & $9 / 19 / 16$ & $+t+$ & 0 & 0 & 1 & 0 & 0 & 0 & 11 & 0 & 0 & 0 & 0 & & \\
\hline & $10 / 10 / 16$ & + & \pm & 0 & 30 & $\mathfrak{1}$ & 1 & 1 & 11 & 1 & 0 & 0 & 0 & & \\
\hline & $10 / 31 / 16$ & + & $\ldots$ & 0 & 3 & 1 & 1 & 1 & 1.50 & 0 & 0 & 0 & 0 & & \\
\hline & $11 / 21 / 16$ & + & 0 & Faint + & 7 & 1 & 1 & 1 & 22 & 2 & 0 & 0 & 0 & & \\
\hline & $12 / 12 / 16$ & $+t+$ & 0 & Faint+ & 8 & 1 & 1 & 1 & 22 & 0 & 0 & 0 & 0 & & \\
\hline & $1 / 3 / 17$ & + & 0 & 0 & 3 & 1 & 1 & 2 & 22 & 3 & 1 & 0 & 0 & & \\
\hline & $1 / 26 / 17$ & + & 0 & 0 & 6 & 1 & 1 & 1 & 10 & 0 & 0 & 0 & 0 & & \\
\hline & $4 / 16 / 17$ & + & \pm & 0 & 0 & 1 & 1 & 2 & 00 & 0 & 0 & 0 & 0 & & . \\
\hline & $5 / 7 / 17$ & + & 0 & 0 & 10 & 1 & 1 & 1 & 10 & 0 & 0 & 0 & 0 & & \\
\hline & $5 / 29 / 17$ & \pm & 0 & 0 & 4 & 1 & 1 & & & 0 & 0 & 0 & 0 & & \\
\hline
\end{tabular}


TABLE 1,-Tabes Dorsalis-Twenty-Four Cases-(Continued)

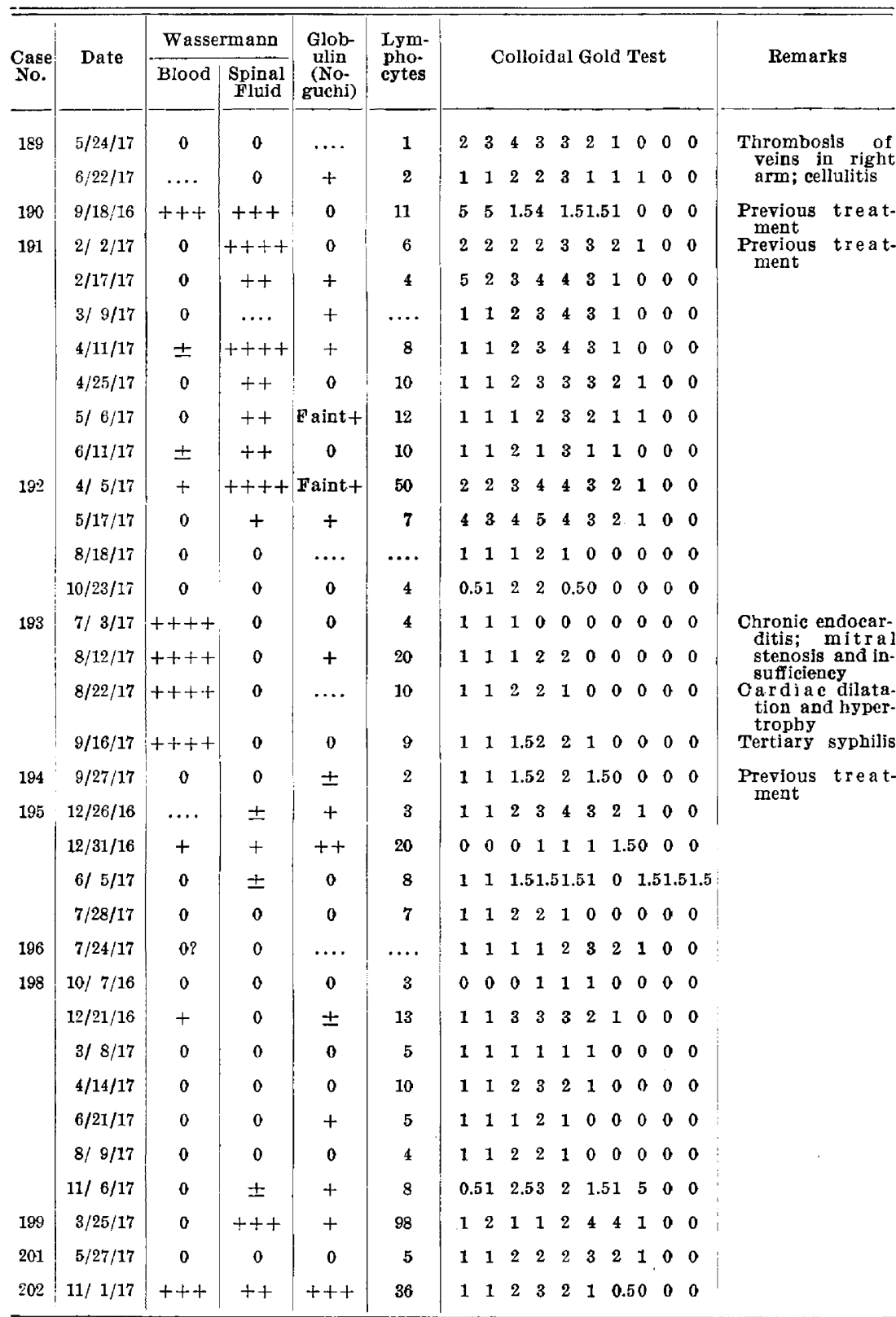

curve in most cases was in the syphilitic zone, though with a tendency to be displaced somewhat to the right, and in not quite half of the cases the peak of the curve reached 4 on the color scale. In one case (No. 180) one curve obtained was of the meningitic type, while a 
later one was in the paretic zone, and two other patients (182 and 190) also gave paretic curves. In both of these, the Wassermann ${ }^{12}$ was positive in both the blood and spinal fluid, but the globulin reaction was negative and the cells were not increased. Of the 24 cases, the blood Wassermann was negative in 8 and doubtful in 2, but 5 of these had already had active antisyphilitic treatment. The spinal fluid Wassermann was negative in 9, and doubtful in 1 case, and 3 of these were cases in which there had already been active treatment. The globulin reaction was negative in 5 cases, and the cells were below 10 in 5 cases. The gold reaction was therefore by far the most reliable index of the pathologic condition of the spinal fluid. In 9 cases in which repeated examinations were made at intervals while the patients were undergoing treatment by the intraspinal injection of arsphenamized serum, a distinct progressive flattening of the curves could be seen, which was in accord with the change in the clinical condition, and appears to be an objective indication of improvement which is rather more delicate than the decrease in the cells and in the globulin reaction.

Cerebrospinal Syphilis. - There are 22 cases of cerebrospinal syphilis in our series. The blood Wassermann was positive in 9, negative in 7 , and doubtful in 4 cases, and in 2 the reaction was not determined. The spinal fluid Wassermann was positive in 15, negative in 5 , and doubtful in 2 cases. The globulin reaction was positive in 19 and negative in 3 cases, and the cells were over 10 in 13 , and 10 or under in 9 cases. The gold reaction was pathologic in all cases but 2 , though the average elevation of the peak was not quite so high as that in tabes. In the latter condition 4 or over in the color scale was reached in 46 per cent. of the cases, and 3 or over in 83 per cent., while in cerebrospinal syphilis the respective figures are 31 per cent. and 72 per cent. The distinction, however, has not very much differential diagnostic value. In two cases the gold curve was only of the irritation type; that is, with no tube showing a color value greater than 1.5. In both of these the globulin reaction was positive; in one the blood Wassermann was positive, but the spinal fluid Wassermann was negative, while in the other, the spinal fluid Wassermann was positive and the blood Wassermann was not tested. Here again the gold reaction appears to be the most reliable single test, though the globulin reaction is little behind it in value.

12. The Wassermann reactions were performed under the direction of Dr. L. W. Famulener. The technic included the use of an antisheep hemolytic system and waterbath fixation. Two antigens were used, namely, the Noguchi acetone-insoluble, and alcoholic extract of guinea-pig heart, and in each case the reaction was performed in duplicate with two different specimens of antigen. 
Table 2.-Cerebrospinal Syphilis-Twenty-Two Cases

\begin{tabular}{|c|c|c|c|c|c|c|c|c|c|c|c|c|c|c|}
\hline \multirow{2}{*}{$\begin{array}{c}\text { Case } \\
\text { No. }\end{array}$} & \multirow{2}{*}{ Date } & \multicolumn{2}{|c|}{ Wassermann } & \multirow{2}{*}{$\begin{array}{c}\text { Glob- } \\
\text { ulin } \\
\text { (No- } \\
\text { guchi) }\end{array}$} & \multirow{2}{*}{$\begin{array}{l}\text { Lym- } \\
\text { pho- } \\
\text { cytes }\end{array}$} & \multirow{2}{*}{\multicolumn{8}{|c|}{ Colloidal Gold Test }} & \multirow{2}{*}{ Remarks } \\
\hline & & Blood & $\mid \begin{array}{c}\text { Spinal } \\
\text { Fluid }\end{array}$ & & & & & & & & & & & \\
\hline \multirow[t]{4}{*}{105} & $5 / 17 / 17$ & 0 & + & + & 80 & 1 & 11 & 1 & 12 & & 11 & 11 & & \\
\hline & $6 / 1 / 17$ & 0 & 0 & + & $\ldots$ & 1 & 23 & 2 & 22 & 0 & 00 & 00 & & \\
\hline & $6 / 21 / 17$ & 0 & 0 & + & 1 & 1 & 23 & 2 & 22 & 0 & $0 \quad 0$ & 00 & & \\
\hline & $9 / 13 / 17$ & 0 & 0 & $\cdots$ & 7 & 1 & 1.52 & 2 & 10 & 0 & 00 & 00 & 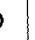 & \\
\hline \multirow[t]{3}{*}{106} & $8 / 29 / 17$ & ++++ & ++++ & 0 & 3 & 1 & 11 & 2 & 33 & 2 & 11 & 10 & & \\
\hline & $9 / 8 / 17$ & ++++ & ++++ & + & 4 & 1 & 11 & 1.5 & 51.52 & 1 & 10 & 00 & & \\
\hline & $9 / 16 / 17$ & $\cdots$ & $\ldots$ & $\cdots$ & 6 & 1 & $2 \quad 2.5$ & 53 & 32 & 2 & $\begin{array}{ll}0 & 0\end{array}$ & 00 & & \\
\hline \multirow[t]{2}{*}{107} & $6 / 19 / 17$ & 0 & +++ & + & 50 & 2 & $3 \quad 3$ & 3 & 21 & 1 & $\begin{array}{ll}0 & 0\end{array}$ & 00 & 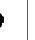 & \\
\hline & $8 / 10 / 17$ & 0 & 0 & + & 12 & $I$ & 23 & 3 & 21 & 0 & $\begin{array}{ll}0 & 0\end{array}$ & 00 & & \\
\hline \multirow[t]{7}{*}{108} & $11 / 7 / 16$ & 0 & 0 & 0 & 1 & 1 & 1.51 .5 & 51 & 10 & 0 & 00 & 00 & & . \\
\hline & $12 / 3 / 16$ & $\ldots$ & ... & Faint + & 14 & 1 & 11 & 1 & 11 & 0 & 00 & 00 & & \\
\hline & $1 / 9 / 17$ & 0 & 0 & 0 & 3 & 1 & 11 & 1 & $\begin{array}{ll}0 & 0\end{array}$ & 0 & $\begin{array}{ll}0 & 0\end{array}$ & 00 & & \\
\hline & $2 / 10 / 17$ & \pm & 0 & 0 & 9 & 2 & 21 & 1 & 10 & 0 & $\begin{array}{ll}0 & 0\end{array}$ & 00 & & \\
\hline & $3 / 2 / 17$ & 0 & 0 & 0 & 2 & 1 & 11 & 1 & 10 & 0 & 00 & 00 & & \\
\hline & $3 / 16 / 17$ & 0 & 0 & Faint + & 6 & 1 & 22 & 2 & 11 & 0 & $\begin{array}{ll}0 & 0\end{array}$ & $\begin{array}{ll}0 & 0\end{array}$ & 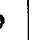 & \\
\hline & $8 / 10 / 17$ & 0 & 0 & + & 20 & 2 & 21 & 1 & 00 & 0 & 00 & $\begin{array}{ll}0 & 0\end{array}$ & 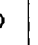 & \\
\hline \multirow[t]{9}{*}{109} & $10 / 4 / 16$ & + & 0 & + & 12 & 0 & 00 & 0 & 00 & 0 & $\begin{array}{ll}0 & 0\end{array}$ & 00 & & \\
\hline & $11 / 7 / 16$ & 0 & $\ldots$ & 0 & 1 & 0 & 11 & 1 & 00 & 0 & $\begin{array}{ll}0 & 0\end{array}$ & $\begin{array}{ll}0 & 0\end{array}$ & 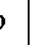 & \\
\hline & $12 / 14 / 16$ & $\ldots$ & $\ldots$ & 0 & 4 & 1 & 11 & 1 & 11 & 0 & 00 & 00 & 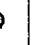 & \\
\hline & $2 / 6 / 17$ & 0 & 0 & $\ldots$. & ... & 1 & 11 & 0 & 00 & 0 & 00 & 00 & 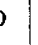 & \\
\hline & $3 / 11 / 17$ & 0 & 0 & 0 & 3 & 1 & 11 & 0 & $\begin{array}{ll}0 & 0\end{array}$ & 0 & 00 & 00 & 0 & \\
\hline & $4 / 11 / 17$ & \pm & ++ & $\cdots$ & 5 & 1 & 23 & 2 & 10 & 0 & 00 & 00 & 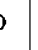 & \\
\hline & $6 / 5 / 17$ & 0 & 0 & 0 & 4 & 0 & 01 & 1 & 01 & 1 & 11 & 11 & 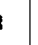 & \\
\hline & $7 / 1 / 17$ & 0 & 0 & $?$ & 4 & 1 & 11 & 2 & 10 & 0 & 00 & 00 & 0 & \\
\hline & $8 / 17 / 17$ & 0 & 0 & $\ldots$ & 8 & 1 & 11 & 0 & $\begin{array}{ll}0 & 0\end{array}$ & 0 & 00 & 00 & 0 & \\
\hline \multirow[t]{4}{*}{110} & $8 / 9 / 17$ & 0 & 0 & 0 & 3 & 1 & 22 & 1 & $\begin{array}{ll}0 & 0\end{array}$ & 0 & 00 & $\begin{array}{ll}0 & 0\end{array}$ & 0 & \multirow{12}{*}{$\begin{array}{l}\text { Chronic nephritis } \\
\text { Tumor of spinal } \\
\text { cord }\end{array}$} \\
\hline & $8 / 12 / 17$ & 3 & $\ldots$ & 0 & 7 & 1 & 11 & 2 & 00 & 0 & $\begin{array}{ll}0 & 0\end{array}$ & 00 & 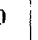 & \\
\hline & $9 / 30 / 17$ & 0 & 0 & 0 & 3 & 1 & 22 & 2 & 21 & 0 & 00 & 00 & 0 & \\
\hline & $11 / 3 / 17$ & \pm & 0 & 0 & 5 & 0.5 & 512 & 1.5 & 50.50 .5 & 50 & 00 & 00 & 0 & \\
\hline 111 & $3 / 22 / 17$ & 0 & \pm & 0 & 4 & 1 & 12 & 3 & 21 & 0 & 00 & 00 & 9 & \\
\hline 112 & $3 / 1 / 17$ & $+++t$ & $+t$ & + & 24 & 1 & 11 & 2 & 32 & 2 & 10 & 00 & 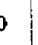 & \\
\hline 113 & $6 / 1 / 17$ & 0 & ++ & ++ & 10 & 1 & 11 & 1 & 1.52 & 3 & 1.51 & 10 & 0 & \\
\hline & 6/ $5 / 17$ & $\cdots$ & + & + & 6 & 5 & 53 & 3 & 43 & 3 & 11 & 10 & 0 & \\
\hline \multirow[t]{4}{*}{114} & $7 / 27 / 17$ & $\ldots$ & ++ & ++ & 200 & 5 & 11 & 2 & 34 & 2 & $\begin{array}{ll}0 & 0\end{array}$ & $\begin{array}{ll}0 & 0\end{array}$ & 0 & \\
\hline & $7 / 31 / 17$ & $\ldots$. & $\ldots$ & $\ldots$ & $\ldots$. & 1 & 12 & 3 & 32 & 1 & 00 & 00 & 0 & \\
\hline & $8 / 14 / 17$ & $\ldots$. & +++ & $\ldots$ & $\ldots$. & 1 & 13 & 4 & 22 & 1 & 00 & $\begin{array}{ll}0 & 0\end{array}$ & 0 & \\
\hline & $10 / 17 / 17$ & $\ldots$ & + & $\ldots$ & $\ldots$ & 1 & I 1.5 & 52 & 1.51 .5 & 50 & 00 & 00 & 0 & \\
\hline
\end{tabular}


TABle 2.-Cerebrospinal Syphilis-Twenty-Two Cases-(Continued)

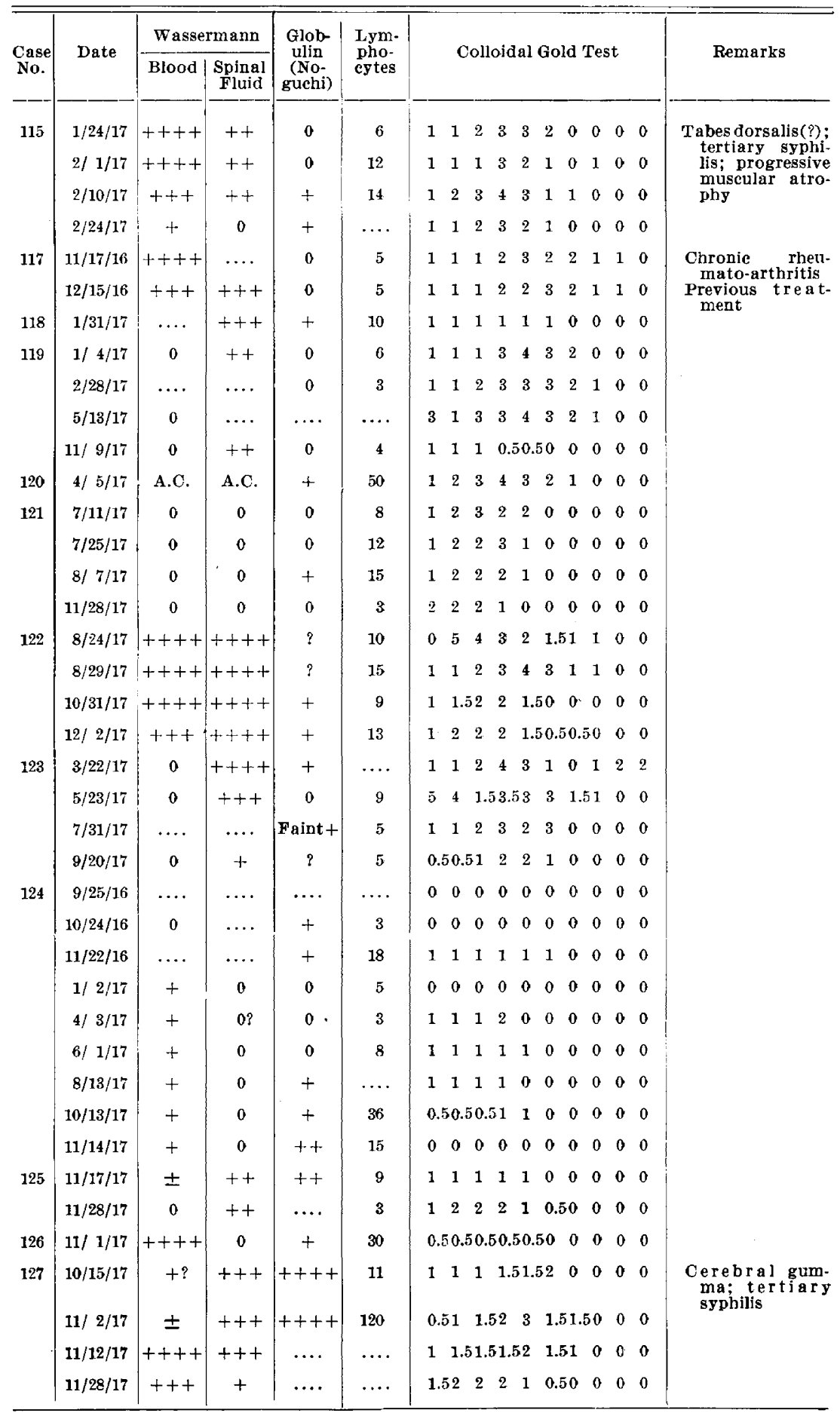


Paresis.-In the group clinically diagnosed as paresis, comprising 6 cases, the blood Wassermann was negative in 1 , the spinal fluid Wassermann in 2, and the cells under 10 in 2 cases, while the gold curve was of the irritation type in 1 instance. In 2 cases the curve was of the syphilitic type, once with both Wassermann reactions posi-

TABle 3.-General Paresis-Six Cases

\begin{tabular}{|c|c|c|c|c|c|c|c|c|c|c|c|c|c|c|c|}
\hline \multirow{2}{*}{$\begin{array}{l}\text { Case } \\
\text { No. }\end{array}$} & \multirow{2}{*}{ Date } & \multicolumn{2}{|c|}{ Wassermann } & \multirow{2}{*}{$\begin{array}{c}\text { Glob- } \\
\text { ulin } \\
\text { (No- } \\
\text { guchi) } \\
\end{array}$} & \multirow{2}{*}{$\begin{array}{l}\text { Lym- } \\
\text { pho- } \\
\text { cytes }\end{array}$} & \multirow{2}{*}{\multicolumn{9}{|c|}{ Colloidal Gold Test }} & \multirow[t]{2}{*}{ Remarks } \\
\hline & & Blood & $\begin{array}{c}\text { Spinal } \\
\text { Fluid }\end{array}$ & & & & & & & & & & & & \\
\hline \multirow[t]{12}{*}{203} & $9 / 16 / 16$ & ++++ & ++++ & + & 6 & 4 & 4 & & 52 & 1 & 1 & 1 & 00 & $\begin{array}{ll}0 & 0\end{array}$ & \multirow[t]{12}{*}{ Tertiary syphilis } \\
\hline & $9 / 29 / 16$ & ++++ & ++++ & + & 5 & 5 & 4 & 1 & 2 & 2 & 2 & 1.5 & 500 & $\begin{array}{ll}0 & 0\end{array}$ & \\
\hline & $10 / 16 / 16$ & ++++ & ++++ & + & 16 & 1.5 & & & 52 & 3 & 3 & 1. & 500 & $0 \quad 0$ & \\
\hline & $11 / 7 / 16$ & ++++ & ++++ & + & 12 & 4 & 2 & 2 & 3 & 2 & 2 & 0 & 00 & 00 & \\
\hline & $11 / 25 / 16$ & $t+t+$ & ++++ & ++ & 12 & 3 & 3 & 2 & 2 & 2 & 2 & 0 & 00 & $0 \quad 0$ & \\
\hline & $12 / 16 / 16$ & ++++ & ++++ & & $\cdots$ & 2 & 2 & 2 & 3 & 3 & 3 & 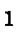 & 00 & 00 & \\
\hline & $1 / 5 / 17$ & ++++ & ++++ & + & 6 & 1 & 1 & 2 & 4 & 3 & 2 & I & 10 & $0 \quad 0$ & \\
\hline & $2 / 3 / 17$ & +++ & ++++ & 0 & 3 & 2 & 2 & 1 & 1 & 1 & 1 & 0 & 00 & $\begin{array}{ll}0 & 0\end{array}$ & \\
\hline & $3 / 6 / 17$ & ++++ & +++ & + & 59 & 1 & 1 & 2 & 3 & 4 & 3 & 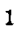 & 10 & 00 & \\
\hline & $4 / 7 / 17$ & ++++ & ++++ & + & 40 & 3 & 3 & 2 & 1 & 0 & 0 & 0 & 00 & $\begin{array}{ll}0 & 0\end{array}$ & \\
\hline & $5 / 8 / 17$ & +++ & +++ & + & 34 & 1 & 1 & 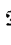 & 3 & 3 & 2 & 3 & 00 & $\begin{array}{ll}0 & 0\end{array}$ & \\
\hline & $6 / 19 / 17$ & ++ & ++ & ++ & 350 & 1 & 2 & 2 & 3 & 3 & 2 & 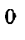 & 00 & $\begin{array}{ll}0 & 0\end{array}$ & \\
\hline 204 & $1 / 9 / 17$ & \pm & 0 & 0 & 6 & 1 & 1 & 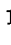 & 1 & 1 & 0 & 0 & 00 & $\begin{array}{ll}0 & 0\end{array}$ & \multirow{7}{*}{$\begin{array}{c}\text { Previous treat- } \\
\text { ment }\end{array}$} \\
\hline \multirow[t]{2}{*}{205} & $6 / 7 / 17$ & +++ & ++++ & + & . & 5 & 3 & 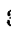 & 4 & 4 & 3 & 3 & 11 & 10 & \\
\hline & $6 / 21 / 17$ & +++ & +++ & + & 7 & 5 & 5 & 3 & 4 & 4 & 1 & 1 & 01 & 10 & \\
\hline \multirow[t]{4}{*}{206} & $7 / 21 / 16$ & A. $\mathrm{C}$. & ++++ & + & 8 & 5 & 5 & 5 & 5 & $\overline{5}$ & 5 & 5 & 21 & 1.50 & \\
\hline & $7 / 26 / 16$ & ++++ & $1+++$ & + & 11 & 5 & 5 & 5 & 5 & 5 & 1. & 1 & 00 & $\begin{array}{ll}0 & 0\end{array}$ & \\
\hline & $11 / 5 / 16$ & ++++ & ++++ & $\div$ & 14 & 5 & 5 & 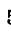 & 5 & 5 & 5 & 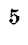 & 1.50 & $\begin{array}{ll}0 & 0\end{array}$ & \\
\hline & $11 / 22 / 16$ & +++ & ++++ & ++ & 36 & 4 & 4 & 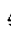 & 4 & 4 & 4 & 3. & 51.51 & 10 & \\
\hline \multirow[t]{2}{*}{207} & $11 / 16 / 16$ & 0 & 0 & + & 15 & 1 & 1 & & 51.5 & 51.5 & 51 & 1 & 00 & 00 & \multirow{6}{*}{$\begin{array}{l}\text { Syphilitic aortitis } \\
\text { with aortic and } \\
\text { mitral regurgi } \\
\text { tation; cardiac } \\
\text { hypertrophy }\end{array}$} \\
\hline & $11 / 20 / 16$ & & 0 & $+t$ & 30 & 1 & 1 & & 2 & 2 & 2 & 0 & 00 & $\begin{array}{ll}0 & 0\end{array}$ & \\
\hline \multirow[t]{4}{*}{208} & $9 / 26 / 16$ & + & +++ & + & 9 & 1 & 1 & & 53. & 2 & 1. & 50 & 00 & $\begin{array}{ll}0 & 0\end{array}$ & \\
\hline & $10 / 10 / 16$ & 0 & +++ & 0 & 12 & 1 & 1 & & 1 & 1.5 & 51 & 1 & 0 & 00 & \\
\hline & $12 / 8 / 16$ & \pm & +++ & $+?$ & 12 & 1 & 2 & 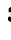 & 3 & 3 & 2 & 2 & 0 & $\begin{array}{ll}0 & 0\end{array}$ & \\
\hline & $1 / 10 / 17$ & 0 & 0 & 0 & 6 & 1 & 1 & & 2 & 1 & 1 & 0 & 00 & $\begin{array}{ll}0 & 0\end{array}$ & \\
\hline
\end{tabular}

tive and once with both negative, but the others gave the characteristic paretic high level for the left hand tubes.

Tertiary Syphilis.-Of tertiary syphilis there are 24 cases in the series. In all of these, except one (No. 145), the Wassermann was positive in either the blood or spinal fluid or both, and in this case there had been active antisyphilitic treatment. The blood Wassermann 
Table 4.-Tertiary Syphilis-Twenty-Two Cases

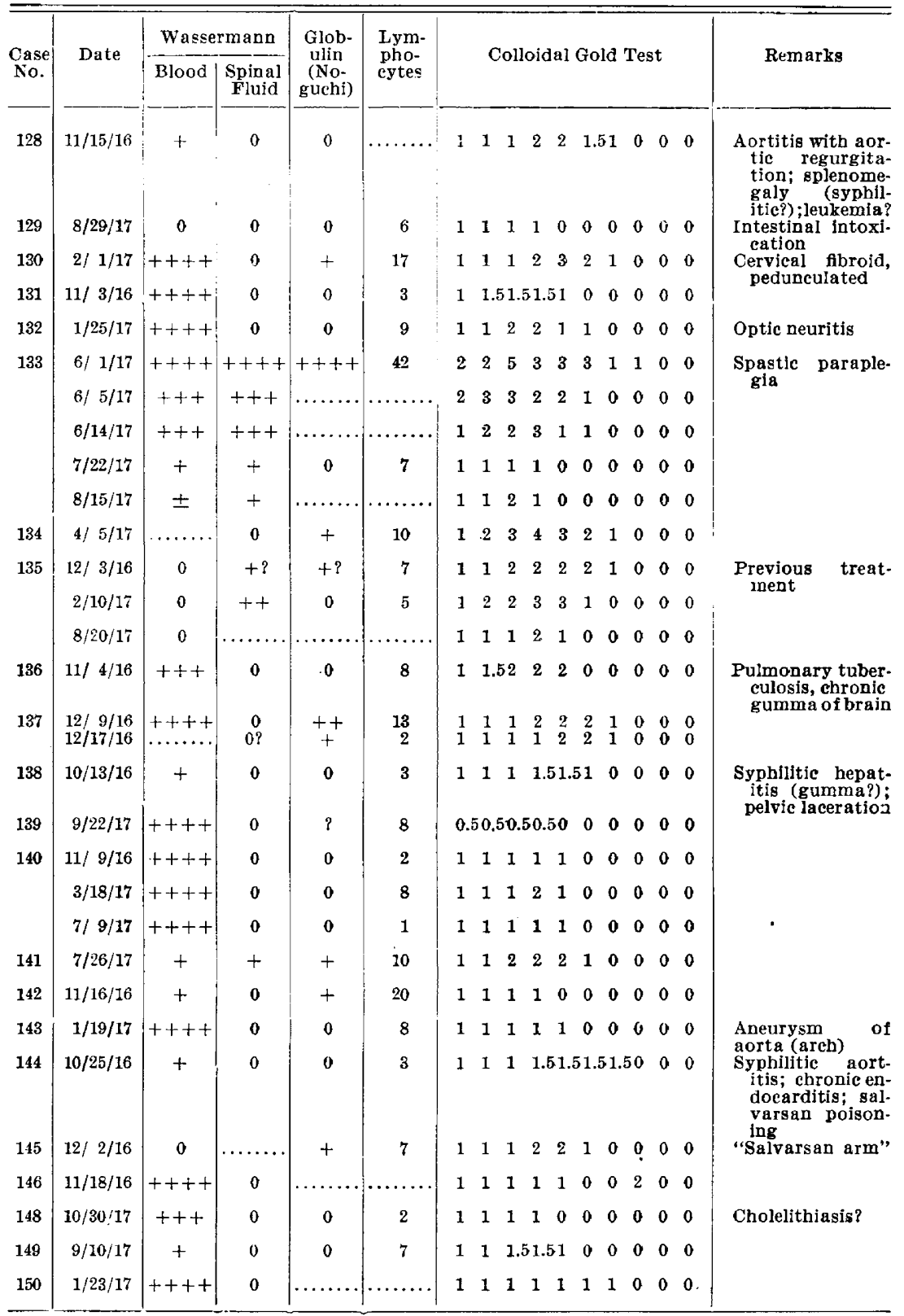

was positive in 16 cases, negative in 5 cases, and in another was not performed. The spinal fluid Wassermann was positive in 3 cases, was negative in 17, and was not performed in 2 cases. The globulin test was positive in 9 cases, negative in 10, and in 3 instances was not 
made. The cells were 10 or under in 18 cases, and above 10 in 4 cases. The gold curve was in the syphilitic zone in 11 cases, and of the irritation type in 11 . Of the 16 cases giving a positive blood Wassermann, 5 gave a negative spinal fluid Wassermann (Nos. 128, 130, 132, 136 and 137) but a gold curve in the syphilitic zone. In these 5 cases

TABle 5.-Acute Anterior Poliomyelitis--Three Cases

\begin{tabular}{|c|c|c|c|c|c|c|c|c|c|c|c|c|c|c|}
\hline $\begin{array}{l}\text { Case } \\
\text { No. }\end{array}$ & Date & $\underset{\text { cytes }}{\text { Lympho- }}$ & $\begin{array}{c}\text { Poly- } \\
\text { nuclear } \\
\text { Leuko- }\end{array}$ & $\begin{array}{l}\text { Glob- } \\
\text { ulin } \\
\text { (No- }\end{array}$ & & & & 110 & dal & Gol & $\mathrm{T}$ & & & \\
\hline 170 & $7 / 20 / 16$ & 4 & 0 & 0 & 5 & 4 & 2 & 1 & 0 & 0 & 0 & 0 & 0 & 0 \\
\hline 171 & $6 / 9 / 17$ & 6 & 0 & + & 1 & 1 & 1 & 2 & 3 & 1 & 1 & 1 & 0 & 0 \\
\hline 172 & $6 / 8 / 17$ & 3 & 0 & Faint + & 1 & 1 & 2 & 1 & 0 & 0 & 0 & 0 & 0 & 0 \\
\hline
\end{tabular}

* The Wassermann reactions on blood and spinal fluid were negative in every case.

TABLE 6.-Congenital Syphilis-Four Cases

\begin{tabular}{|c|c|c|c|c|c|c|c|c|c|c|c|c|c|c|c|}
\hline \multirow{2}{*}{$\begin{array}{c}\text { Case } \\
\text { No. }\end{array}$} & \multirow{2}{*}{ Date } & \multicolumn{2}{|c|}{ Wassermann } & \multirow{2}{*}{$\begin{array}{l}\text { Glob- } \\
\text { ulin } \\
\text { (No- } \\
\text { guchi) }\end{array}$} & \multirow{2}{*}{$\begin{array}{l}\text { Lym- } \\
\text { pho- } \\
\text { cytes }\end{array}$} & \multirow{2}{*}{\multicolumn{9}{|c|}{ Colloldal Gold Test }} & \multirow{2}{*}{ Remarks } \\
\hline & & Blood & $\begin{array}{l}\text { Spinal } \\
\text { Fluid }\end{array}$ & & & & & & & & & & & & \\
\hline 173 & $8 / 29 / 17$ & $\ldots \ldots$ & $0^{*}$ & 0 & 4 & 1 & 1 & 1 & 11 & 0 & 0 & 00 & 0 & 0 & \\
\hline \multirow[t]{2}{*}{174} & $9 / 10 / 17$ & $\cdots \cdots$ & 0 & $?$ & 8 & 1 & 1 & 1 & 10 & 0 & 0 & 00 & 0 & 0 & \\
\hline & $11 / 11 / 17$ & ++++ & $0 ?$ & 0 & 4 & 0 & 0 & 0 & $\begin{array}{ll}0 & 0\end{array}$ & 0 & 0 & 0 & 0 & 0 & \\
\hline \multirow[t]{6}{*}{175} & $2 / 21 / 17$ & ..... & ++++ & + & 30 & 1 & 1 & 2 & 21 & 0 & 0 & 0 & 0 & 0 & \\
\hline & $3 / 15 / 17$ & ++++ & A. C. & + & 9 & 1 & 2 & 3 & 21 & $I$ & 0 & 0 & 0 & 0 & \\
\hline & $5 / 27 / 17$ & + & \pm & $+?$ & 5 & 1 & 2 & 3 & 32 & 2 & 0 & 0 & 0 & 0 & \\
\hline & $7 / 1 / 17$ & $\ldots \ldots$ & 0 & 0 & 4 & 1 & 2 & 3 & 21 & $I$ & 0 & 0 & 0 & 0 & \\
\hline & $9 / 23 / 17$ & ...... & $\ldots \ldots$ & 0 & 4 & 1 & 1 & 1 & 0.50 .5 & 50 & 0 & 0 & 0 & 0 & \\
\hline & $10 / 27 / 17$ & $\ldots \ldots$ & \pm & ...... & 5 & 1 & 1 & 1 & 10 & 0 & 0 & 0 & 0 & 0 & \\
\hline \multirow[t]{6}{*}{176} & $10 / 9 / 16$ & + & 0 & $\ldots \ldots$ & ...... & 1 & 1 & 1 & 11 & 0 & 0 & 0 & 0 & 0 & \\
\hline & $1 / 6 / 17$ & \pm & 0 & 0 & 2 & 1 & 1 & 2 & 21 & 0 & 0 & 0 & 0 & 0 & \\
\hline & $5 / 13 / 17$ & $\ldots \ldots$ & $0 ?$ & 0 & 6 & 2 & 2 & 2 & 21 & 1 & 0 & 0 & 0 & 0 & \\
\hline & $6 / 22 / 17$ & 0 & 0 & 0 & 8 & 1 & 1 & 2 & 20 & 0 & 0 & 0 & 0 & 0 & \\
\hline & $8 / 31 / 17$ & 0 & 0 & 0 & 3 & 1 & 1 & 1 & 51.50 & 0 & 0 & 0 & 0 & 0 & \\
\hline & $11 / 11 / 17$ & 0 & 0 & 0 & 4 & 1 & 1 & 0 & 01 & 0 & 0 & 0 & 0 & 0 & \\
\hline
\end{tabular}

$*++++$ before treatment.

the globulin reaction was positive only twice. This indicates one of the most important uses of the gold reaction. It appears to be a more delicate index of syphilitic change in the spinal fluid than the Wassermann and the globulin test, and it is therefore of value in detecting the earliest onset of cerebrospinal lesions. The importance of this in the prophylaxis of the parasyphilitic diseases is evident, 
TABLE 7.-Tuberculous Meningitis-Nine Cases

\begin{tabular}{|c|c|c|c|c|c|c|c|c|c|c|c|c|c|c|c|}
\hline $\begin{array}{l}\text { Case } \\
\text { No. }\end{array}$ & Date & $\begin{array}{l}\text { Lym- } \\
\text { pho- }\end{array}$ & $\begin{array}{l}\text { Poly- } \\
\text { nuclear } \\
\text { Leuko- }\end{array}$ & $\begin{array}{l}\text { Glob- } \\
\text { ulin** } \\
\text { (No- }\end{array}$ & \multicolumn{10}{|c|}{ Colloidal Gold Reaction } & \multirow{2}{*}{$\begin{array}{c}\text { Pulmonary tu } \\
\text { berculosis }\end{array}$} \\
\hline \multirow[t]{3}{*}{152} & $7 / 18 / 16$ & 183 & 20 & ++ & 0 & 1.5 & 2 & 3 & 3.5 & 4 & 4 & 3.5 & 3 & 0 & \\
\hline & $7 / 19 / 17$ & 281 & 29 & 0 & 1 & 1 & 1.5 & 1.5 & 1.5 & 1.5 & 1 & 1 & 1.5 & 0 & \\
\hline & $7 / 21 / 16$ & 140 & 0 & +++ & 1 & 5 & 4 & 1.5 & 1 & 0 & 0 & 0 & 0 & 0 & \\
\hline 153 & $1 / 30 / 17$ & 81 & 0 & + & 1 & 1 & 1 & I & 2 & 2 & 0 & 0 & 0 & 0 & \\
\hline \multirow[t]{3}{*}{154} & $8 / 6 / 17$ & 30 & 1,470 & + & 1 & 1 & 2 & 2 & 1 & 0 & 0 & 0 & 0 & 0 & \\
\hline & $8 / 9 / 17$ & 90 & 210 & + & 4 & 1 & 3 & 2 & 1 & 0 & 0 & 0 & 0 & 0 & \\
\hline & $8 / 10 / 17$ & 324 & 486 & + & 1 & $\ell$ & 1 & 1 & 2 & 3 & 1 & 3 & 0 & 0 & \\
\hline 155 & $8 / 9 / 17$ & 344 & 56 & + & 1 & 1 & 1 & 2 & 2 & 0 & 0 & 0 & 0 & 0 & \\
\hline \multirow[t]{3}{*}{156} & $12 / 5 / 16$ & 171 & 9 & ++ & 1 & 1 & 2 & 2 & 2 & 2 & 1 & 1 & 0 & 0 & \\
\hline & $12 / 6 / 17$ & 393 & 12 & $+t$ & 1 & 1 & 1 & 1 & 2 & 2 & 2 & 1 & 0 & 0 & \\
\hline & $12 / 10 / 16$ & 182 & 15 & ++ & 1 & 1 & 1 & 2 & 3 & 3 & 2 & 1 & 0 & 0 & \\
\hline 157 & $11 / 20 / 16$ & 450 & 0 & ++++ & 1 & 1 & 1 & 1 & 2 & 3 & 3 & 3 & 0 & 0 & \\
\hline 158 & $6 / 26 / 17$ & 90 & 0 & + & 1 & 1 & 1 & 2 & 2 & 1 & 1 & 0 & 0 & 0 & \\
\hline \multirow[t]{2}{*}{159} & $6 / 29 / 17$ & 88 & 0 & + & 1 & 1 & 1 & 1 & 3 & 3 & 1 & 2 & 0 & 0 & \\
\hline & $7 / 2 / 17$ & 98 & 0 & + & 1 & 2 & 1 & 3 & 3 & 4 & 2 & 2 & 0 & 0 & \\
\hline \multirow[t]{2}{*}{74} & $12 / 2 / 16$ & 126 & 0 & + & 1 & 1 & 1 & 2 & 2 & 2 & 0 & 0 & 0 & 0 & \\
\hline & $12 / 5 / 16$ & 316 & 16 & ++ & 1 & 1 & 1 & 1 & 2 & 2 & I & 1 & 0 & 0 & \\
\hline
\end{tabular}

* The Wassermann reaction was negative in every case in which it was performed.

TABLE 8.-Meningitis-Ten Cases

\begin{tabular}{|c|c|c|c|c|c|c|c|c|c|c|c|c|c|}
\hline \multirow{3}{*}{$\begin{array}{c}\begin{array}{c}\text { Case } \\
\text { No. }\end{array} \\
160\end{array}$} & \multirow{2}{*}{ Date } & \multirow{2}{*}{$\begin{array}{r}\begin{array}{c}\text { Lym- } \\
\text { pho- } \\
\text { cytes }\end{array} \\
4\end{array}$} & \multirow{2}{*}{$\begin{array}{c}\text { Poly- } \\
\text { nuclear } \\
\text { Leuko- } \\
\text { cytes } \\
\\
0\end{array}$} & \multirow{2}{*}{$\begin{array}{c}\begin{array}{c}\text { Glob- } \\
\text { ulin* } \\
\text { (No- } \\
\text { guchi) }\end{array} \\
0\end{array}$} & \multicolumn{8}{|c|}{ Colloidal Gold Test } & \multirow{3}{*}{ Serous meningitis } \\
\hline & & & & & 1 & 2 & 3 & 3 & 1 & 00 & 00 & 0 & \\
\hline & $7 / 16 / 17$ & 4 & 0 & 0 & 1 & 1 & 2 & 2 & 2 & 10 & 00 & 0 & \\
\hline 161 & $5 / 15 / 17$ & 1,360 & 5,440 & + & 1 & 1 & 1 & 1 & 1 & 23 & 00 & 0 & $\begin{array}{l}\text { Epidemic } \\
\text { meningitis }\end{array}$ \\
\hline 162 & $5 / 15 / 17$ & 440 & 660 & + & 0 & 0 & 0 & 0 & 1 & 1.50 & 01 & 1 & $\underset{\text { meningitis }}{\text { Epidemic }}$ cerebrospinal \\
\hline 163 & $12 / 21 / 16$ & 152 & 8 & ++ & 0 & 0 & 0 & $\mathbf{0}$ & 0 & 12 & 13 & 1 & $\begin{array}{l}\text { Lobar pneumonia; influ- } \\
\text { enza }\end{array}$ \\
\hline 164 & $3 / 4 / 17$ & 38 & 342 & + & 0 & 0 & 0 & 0 & 0 & 24 & 22 & 1 & $\begin{array}{l}\text { Pneumococcus meningitis, } \\
\text { lobar pneumonia }\end{array}$ \\
\hline 165 & $4 / 24 / 17$ & 140 & 1,260 & + & 0 & 0 & 0 & 0 & 0 & $\begin{array}{ll}0 & 0\end{array}$ & 11. & .52 & $\begin{array}{l}\text { Acute purulent menin- } \\
\text { gitis (pneumococcus); } \\
\text { ethmoiditis, purulent }\end{array}$ \\
\hline 166 & $5 / 28 / 17$ & 3,750 & 8,750 & +++ & 0 & 1. & 50 & 0 & 0 & 1.52 & 1.51 & 1 & Epidemic cerebrospinal \\
\hline 167 & $11 / 17 / 16$ & 267 & 513 & ++++ & 0 & 1 & 1 & 1 & 1 & 13 & 44 & 3 & $\begin{array}{l}\text { Septic meningitis (pneu- } \\
\text { mococcus) }\end{array}$ \\
\hline \multirow[t]{2}{*}{168} & $3 / 22 / 17$ & 280 & 120 & + & 1 & 1 & 2 & 3 & 3 & 20 & $\begin{array}{ll}0 & 0\end{array}$ & 0 & Cerebrospinal meningitis \\
\hline & $4 / 6 / 17$ & 1,400 & 0 & + & 2 & 2 & 3 & 4 & 3 & 21 & 00 & 0 & \\
\hline \multirow[t]{2}{*}{169} & $1 / 22 / 17$ & 64 & 1 & + & 1 & 1 & 1 & 2 & 1 & $\begin{array}{ll}0 & 0\end{array}$ & 00 & 0 & Acute septic mezingitis \\
\hline & $1 / 23 / 17$ & 12 & 0 & \pm & 1 & $\mathbf{1}$ & 1 & 1 & 1 & 00 & 00 & 0 & \\
\hline
\end{tabular}

* In every case in which the Wassermann reaction was performed it was negative. 
and every syphilitic with a positive blood Wassermann should have the colloidal gold reaction done on the spinal fluid in order that proper treatment may be begun at a stage before permanent organic lesions have developed.

Three cases of poliomyelitis gave a pathologic gold curve in each instance, though the cells were below 10 in all three, and in one case the globulin reaction was negative. In one case the curve was in the paretic zone, and in the other two, it was of the syphilitic type.

Four cases of congenital syphilis are recorded. Of these, three gave positive blood Wassermanns, and one gave a positive spinal fluid Wassermann. Two of the cases gave a gold curve in the syphilitic zone, while two, both with negative spinal fluid Wassermann reactions, gave only irritation curves.

There are nine cases of tuberculous meningitis. These all gave curves chiefly in the syphilitic zone. Of ten other cases of nontuberculous meningitis, all except one case of epidemic cerebrospinal meningitis gave curves which for the most part are characterized by a displacement to the right, which is typical of acute meningeal inflammation. One case is of interest because, although the cell count and the globulin reaction were both negative, so that the diagnosis of serous meningitis was made, the gold curve was a well marked one.

We have records of tests in 102 cases of miscellaneous conditions, in many of which pathologic curves were obtained, though not with sufficient regularity to be of definite diagnostic value. For example, of 12 cases of chronic nephritis, 7 gave only irritation curves, while in 4 cases accompanied by uremia, there was a well marked elevation in the syphilitic zone. In one of these the spinal fluid Wassermann was positive, though the cell count and globulin reaction were negative. In another case, there was complete flocking out of the gold in 7 of the 10 tubes. Of 5 cases of hysteria, 4 gave only irritation curves, but 1 with a positive globulin reaction and negative blood and spinal fluid Wassermann gave a syphilitic curve. Out of 3 cases of multiple sclerosis 1 was negative; another with positive blood and spinal fluid Wassermann, globulin reaction, and increased cell count gave first a syphilitic curve and ten days later a paretic curve. A third case in which the diagnosis was somewhat in doubt gave a syphilitic curve, though the blood and spinal fluid Wassermann, globulin, and cell count were all negative. In 2 cases diagnosed as neurasthenia there were curves in the syphilitic zone, though the blood and spinal fluid Wassermann, cell count, and globulin reaction were all negative, which is of interest as indicating a possible organic basis for the symptoms. One of the two cases of epilepsy gave a negative curve, and the other a syphilitic curve, though the other reactions were all negative. Three of the 4 cases of chorea gave negative curves, and the fourth a low 
TABLE 9.-Miscellaneous Conditions-104 Cases

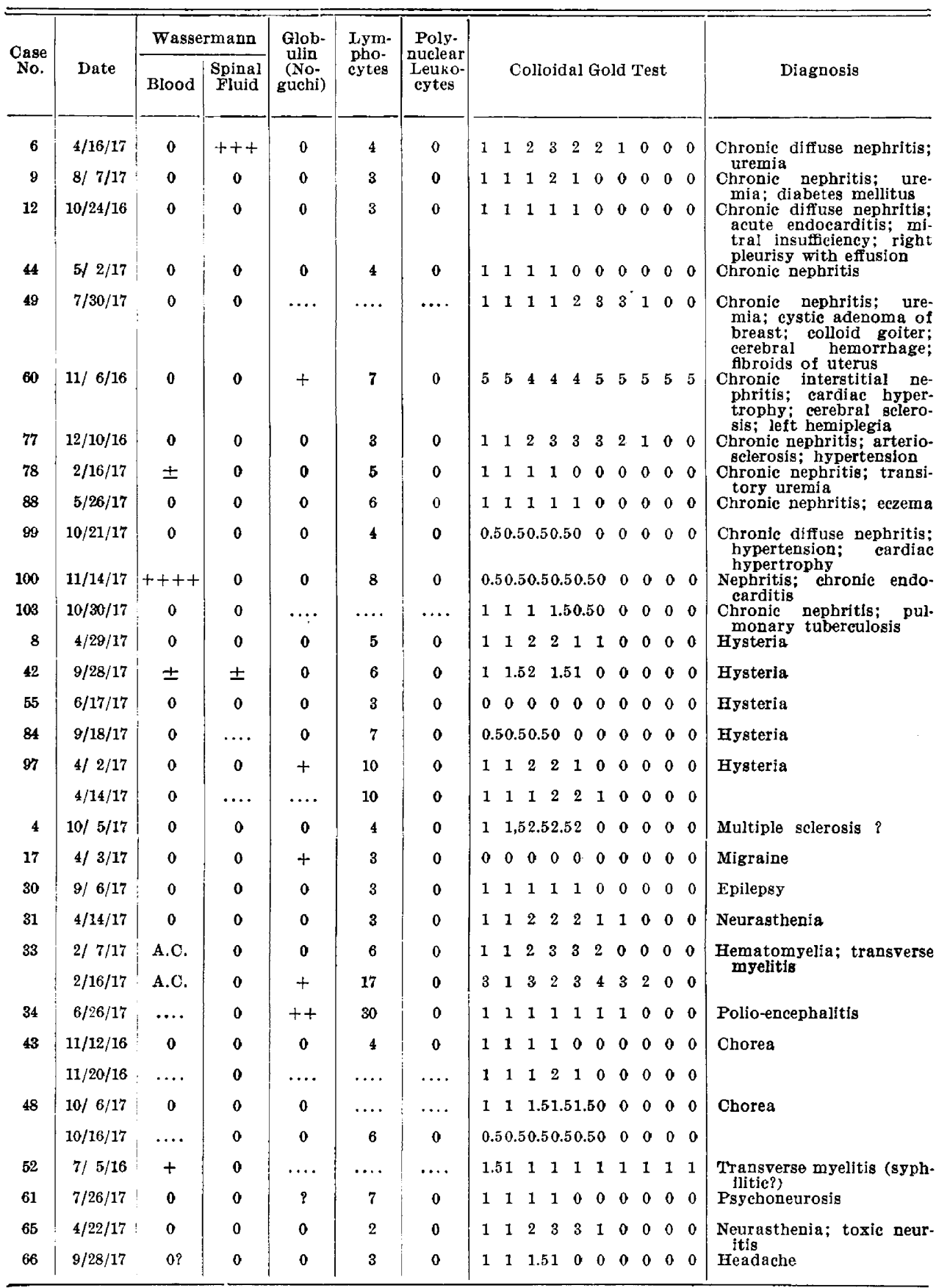


TABLE 9.-Miscellaneous Conditions-104 Cases--(Continued)

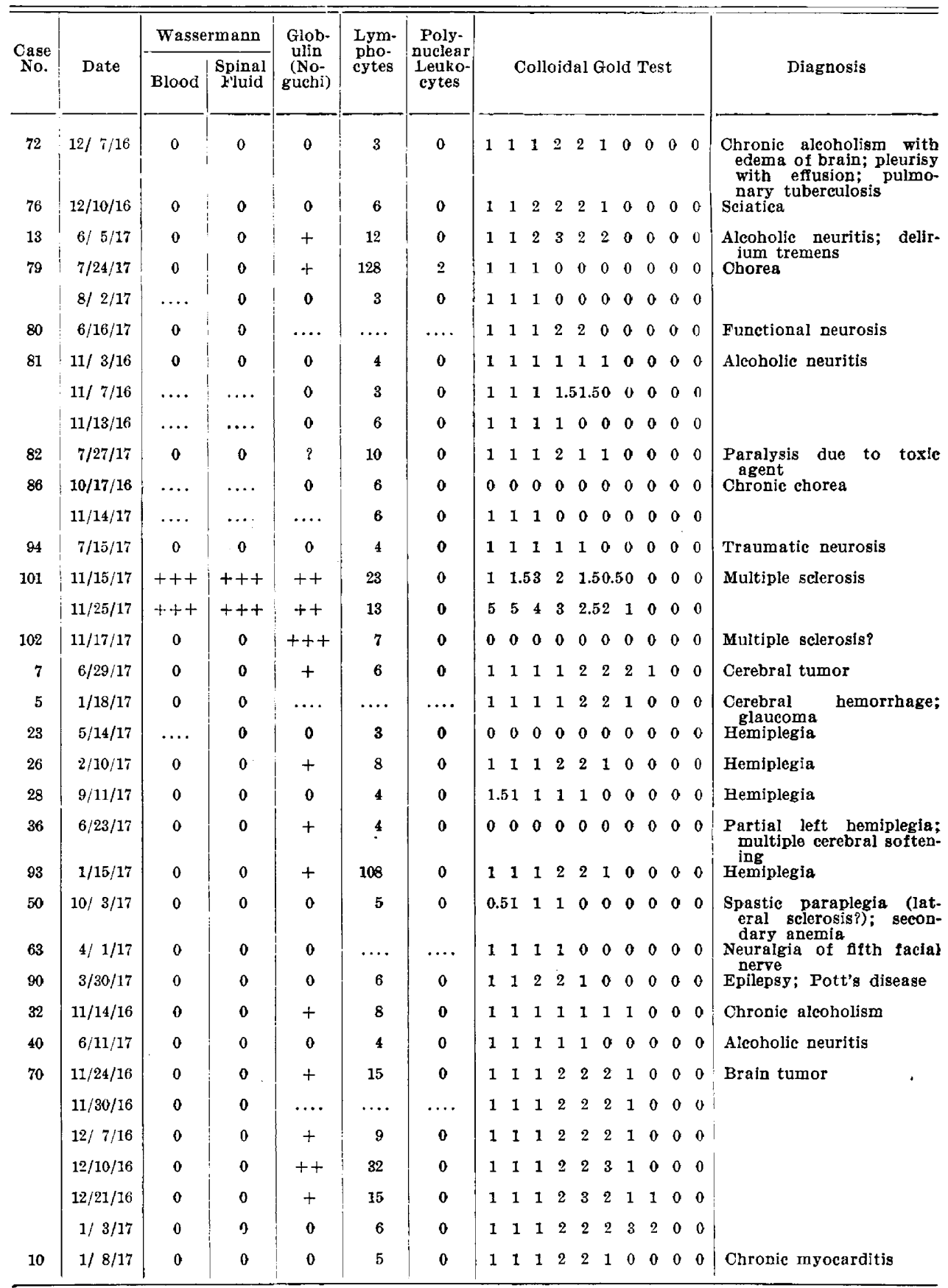


TABle 9.-Miscellaneous Conditions-104 Cases-(Continued)

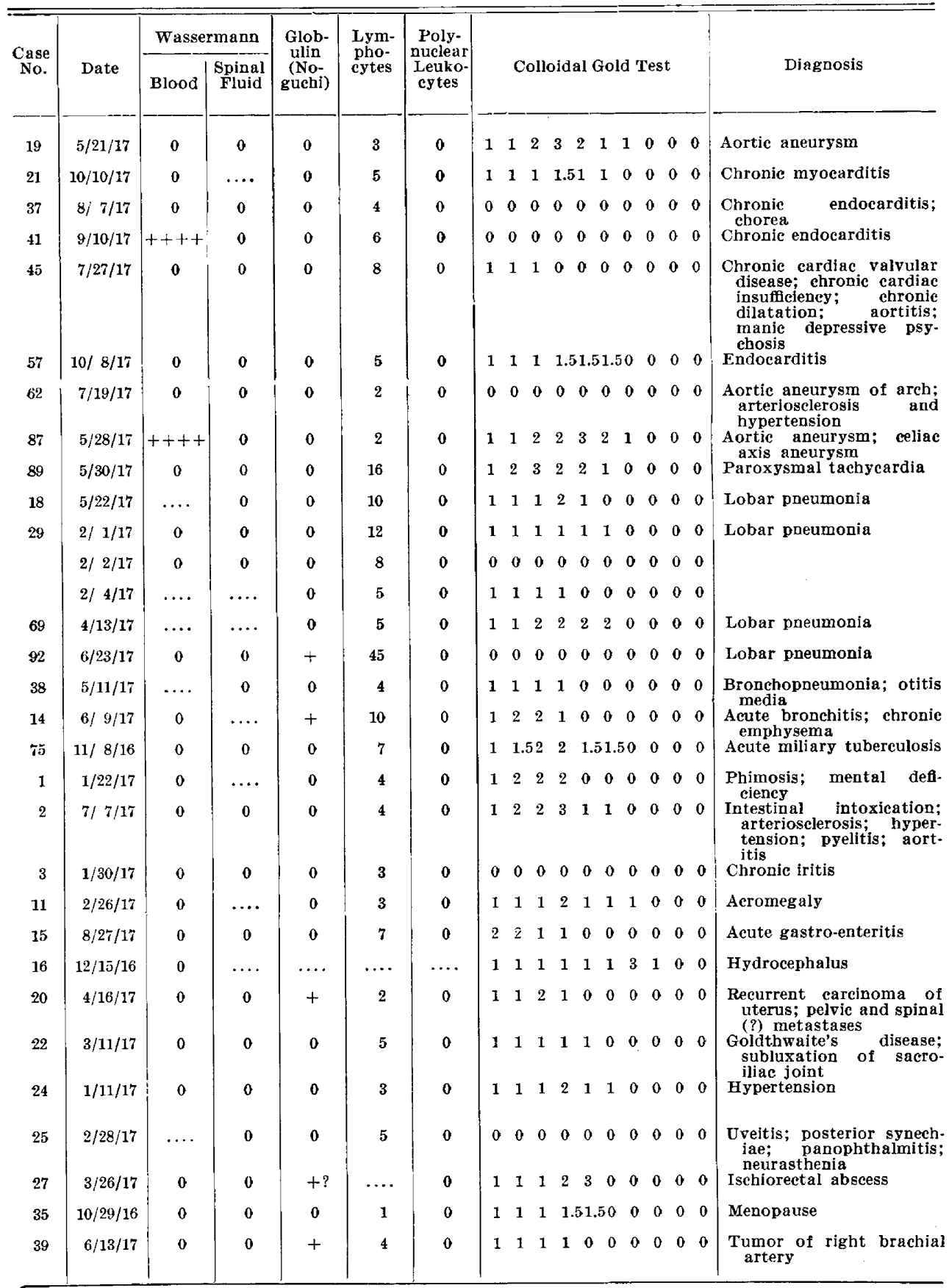


TABLE 9.-Miscellaneous Conditions-104 Cases-(Continued)

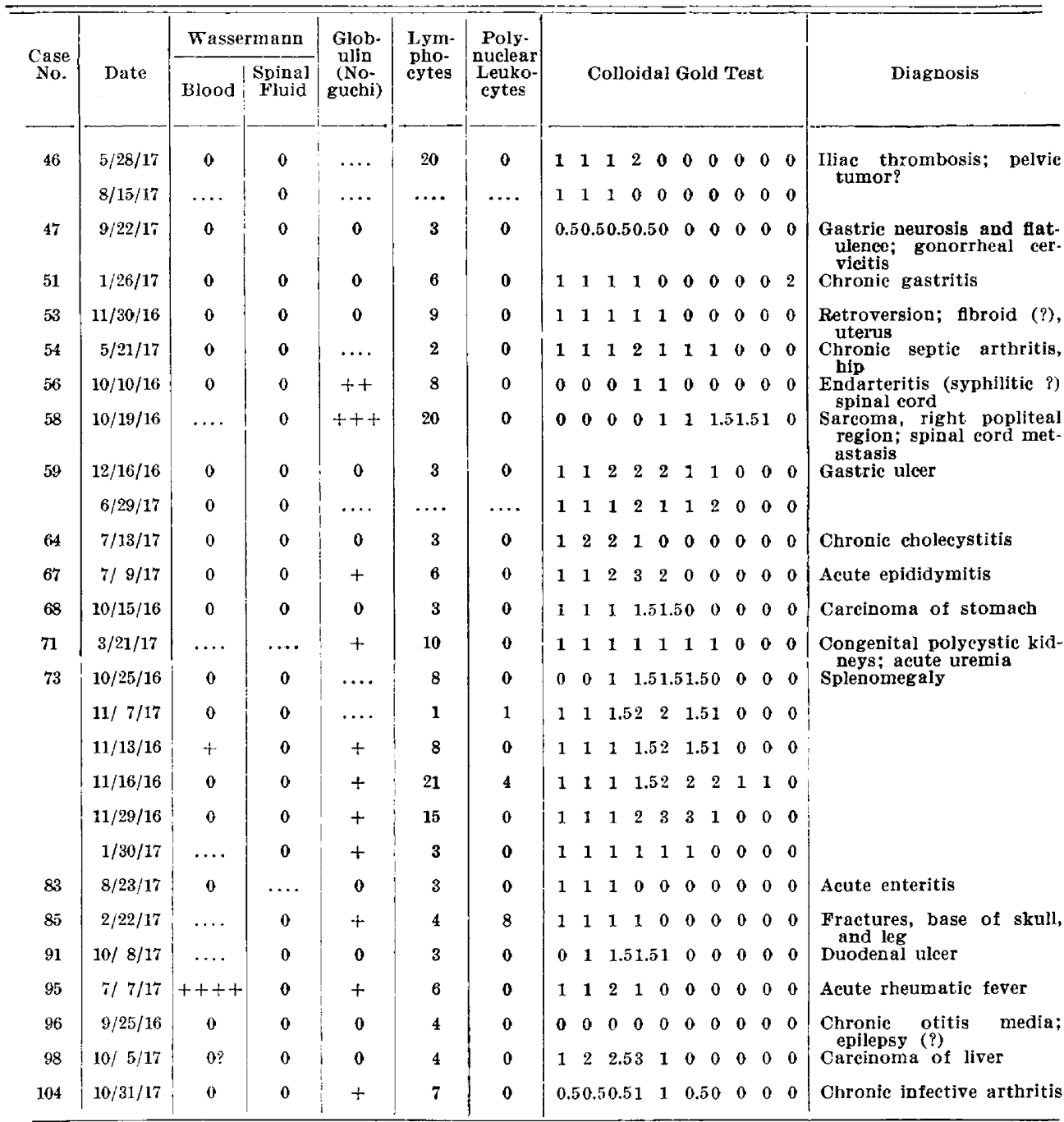

syphilitic curve, the other tests being negative. One case of transverse myelitis gave only an irritation curve, and another a syphilitic curve, the other tests being negative. There were 5 cases of chronic alcoholism. Two of these, one in which the diagnosis of edema of the brain was made, and the other with delirium tremens, gave syphilitic curves, though the Wassermann reactions were negative, but 3 cases with peripheral neuritis gave only irritation curves. Two cases of brain tumor with positive globulin reactions, but negative Wassermann reactions, gave curves showing a slight displacement to the right. Of 5 cases of hemiplegia, 3 gave negative curves and 2 syphilitic 
curves, though the Wassermann tests were negative. A curious observation was that in a case of paroxysmal tachycardia there were 16 cells per cubic millimeter and the gold curve was in the syphilitic zone, though the Wassermanns were negative.

In comparing the gold curve and the spinal fluid Wassermann the following may be said: In our series comprising 24 cases of tabes, 22 of cerebrospinal syphilis, 22 of tertiary syphilis, 6 of general paresis and 4 of congenital syphilis, or 78 altogether, there were no instances in which at the first examination the spinal fluid Wassermann was positive but the gold curve was negative. There were two cases, however, in which the spinal fluid Wassermann was positive and the curve was under two in the scale at the first examination. These were both cases of cerebrospinal syphilis, and in one (No. 118) only a single examination was made, but in the other (No. 125), although the first examination gave a curve under two, a later one showed a good syphilitic reaction.

On the other hand, in these 78 cases there were 33 in which at the first examination the spinal fluid Wassermann was negative, but the gold curve was pathologic in character. In 16 of these cases the curve reached 2 or over in the scale, and it is particularly interesting to note that 7 of these instances occurred in cases of tabes.

\section{CONCLUSIONS}

1. It must be emphasized that each of the different tests on the spinal fluid is of value only as a single factor in the entire examination, and that no one test alone is pathognomonic.

2. The colloidal gold reaction is the most sensitive indicator we have of pathologic changes in the spinal fluid, the globulin reaction closely approaching it in delicacy.

3. Uremia, neurasthenia, serous meningitis, hemiplegia and chronic alcoholism may give a curve in the syphilitic zone.

4. If the gold reaction is negative, it is highly probable that the spinal fluid Wassermann will also be negative.

5. An important application of the gold reaction is in the recognition of the earliest stages of cerebrospinal syphilis, and its routine employment in all syphilitics is to be recommended as an aid in the prophylaxis of the parasyphilitic diseases.

680 Madison Avenue. 